J. Dairy Sci. 92:3069-3073

doi:10.3168/jds.2008-1705

(C) American Dairy Science Association, 2009.

\title{
Technical note: Enumeration of mesophilic aerobes in milk: Evaluation of standard official protocols and Petrifilm aerobic count plates
}

\author{
R. Freitas, ${ }^{*}$ L. A. Nero, $†$ and A. F. Carvalho*1 \\ *Department of Food Technology, and \\ †Department of Veterinary, Federal University of Viçosa, Viçosa MG, Brazil, 36570-000
}

\begin{abstract}
Enumeration of mesophilic aerobes (MA) is the main quality and hygiene parameter for raw and pasteurized milk. High levels of these microorganisms indicate poor conditions in production, storage, and processing of milk, and also the presence of pathogens. Fifteen raw and 15 pasteurized milk samples were submitted for MA enumeration by a conventional plating method (using plate count agar) and Petrifilm Aerobic Count plates (3M, St. Paul, MN), followed by incubation according to 3 official protocols: IDF/ISO (incubation at $30^{\circ} \mathrm{C}$ for $72 \mathrm{~h}$ ), American Public Health Association $\left(32^{\circ} \mathrm{C}\right.$ for $\left.48 \mathrm{~h}\right)$, and Brazilian Ministry of Agriculture $\left(36^{\circ} \mathrm{C}\right.$ for $\left.48 \mathrm{~h}\right)$. The results were compared by linear regression and ANOVA. Considering the results from conventional methodology, good correlation indices and absence of significant differences between mean counts were observed, independent of type of milk sample (raw or pasteurized) and incubation conditions (IDF/ ISO, American Public Health Association, or Ministry of Agriculture). Considering the results from Petrifilm Aerobic Count plates, good correlation indices and absence of significant differences were only observed for raw milk samples. The microbiota of pasteurized milk interfered negatively with the performance of Petrifilm Aerobic Count plates, probably because of the presence of microorganisms that poorly reduce the dye indicator of this system.
\end{abstract}

Key words: milk, mesophilic aerobe, enumeration method, Petrifilm

The quality of milk depends on efficient control during various stages of production, storage, transport, processing, and commercialization. In each of these stages, specific conditions must be properly and constantly monitored, because they can jeopardize the final quality of milk and dairy products. To guarantee adequate monitoring, governmental agencies are responsible for

Received September 12, 2008.

Accepted January 19, 2009.

${ }^{1}$ Corresponding author: antoniofernandes@ufv.br determining parameters and rules that must be followed during all steps of production. These organizations are also responsible for systematic verification of whether these parameters and rules are being met.

In Brazil this regulatory role is conducted by the Ministry of Agriculture [Ministério da Agricultura, Pecuária e Abastecimento (MAPA); Brasil, 2008a] and by the Ministry of Health through the National Agency of Sanitary Vigilance [Ministério da Saúde, Agência Nacional de Vigilância Sanitária (ANVISA); Brasil, 2008b]. An example of these regulations was the Instrução Normativa 51, from MAPA, which was published in 2002 establishing several quality parameters of animal health and quality of raw and pasteurized milk (Brasil, 2002).

The mesophilic aerobes (MA) are indicator microorganisms often used to verify the microbiological quality of milk and dairy products, because they provide valuable information about sanitary and hygienic conditions of milking, storage, and processing, and also suggest the presence of pathogenic microorganisms (ICMSF, 1988). Mesophilic aerobes are able to grow between 20 and $45^{\circ} \mathrm{C}$, with an optimum growth temperature of $32^{\circ} \mathrm{C}$, and include the majority of spoilage and pathogenic microorganisms associated with milk and dairy products (Jay et al., 2005).

Enumeration of MA is conventionally done by pour plating diluted samples in a nonselective culture medium, usually plate count agar, followed by incubation in aerobic conditions at mesophilic temperatures for a specific period of time (Robinson, 2002). Considering these requirements, several combinations of these conditions are described in standard protocols for MA enumeration in foods, including dairy products. The International Dairy Federation (IDF) recommends the incubation of plates at $30^{\circ} \mathrm{C}$ for $72 \mathrm{~h}$ (ISO, 2003); the American Public Health Association (APHA) sets the incubation at $32^{\circ} \mathrm{C}$ for $48 \mathrm{~h}$ (Wehr and Frank, 2004); and MAPA recommends incubation at $36^{\circ} \mathrm{C}$ for $48 \mathrm{~h}$ (Brasil, 2003).

Although it is the official benchmark, traditional microbiological analysis has limited application because it cannot provide instantaneous results for immediate 
Table 1. Mean counts $( \pm \mathrm{SD})$ of mesophilic aerobes $\left(\log _{10} \mathrm{cfu} / \mathrm{mL}\right)$ in raw and pasteurized milk samples obtained by conventional and Petrifilm AC plating ${ }^{1}$ and incubated at 3 distinct conditions

\begin{tabular}{|c|c|c|c|}
\hline \multirow[b]{3}{*}{ Category } & \multicolumn{3}{|c|}{ Incubation conditions } \\
\hline & $30^{\circ} \mathrm{C}, 72 \mathrm{~h}$ & $32^{\circ} \mathrm{C}, 48 \mathrm{~h}$ & $36^{\circ} \mathrm{C}, 48 \mathrm{~h}$ \\
\hline & ISO (2003) & APHA (2004) & Brasil (2003) \\
\hline \multicolumn{4}{|l|}{ Raw milk } \\
\hline Conventional plating & $7.63 \pm 0.29^{\mathrm{a}, \mathrm{A}}$ & $7.53 \pm 0.35^{\mathrm{a}, \mathrm{A}}$ & $7.38 \pm 0.45^{\mathrm{a}, \mathrm{A}}$ \\
\hline Petrifilm AC plating & $7.69 \pm 0.27^{\mathrm{a}, \mathrm{A}}$ & $7.48 \pm 0.35^{\mathrm{a}, \mathrm{A}}$ & $7.33 \pm 0.44^{\mathrm{a}, \mathrm{A}}$ \\
\hline \multicolumn{4}{|l|}{ Pasteurized milk } \\
\hline Conventional plating & $4.14 \pm 0.10^{\mathrm{a}, \mathrm{A}}$ & $3.99 \pm 0.14^{\mathrm{a}, \mathrm{A}}$ & $3.89 \pm 0.17^{\mathrm{a}, \mathrm{A}}$ \\
\hline Petrifilm AC plating & $4.05 \pm 0.10^{\mathrm{a}, \mathrm{A}}$ & $3.51 \pm 0.43^{\mathrm{b}, \mathrm{B}}$ & $2.33 \pm 0.48^{\mathrm{c}, \mathrm{B}}$ \\
\hline
\end{tabular}

or rapid corrective actions (Fung, 2002). In addition, traditional microbiological methods demand preparation of culture media and glassware, requiring valuable work time and material from laboratories (Park et al., 2001; Sant'Ana et al., 2002). Considering these limitations, several alternative microbiological methodologies were developed in the 1970s, known as rapid methods (Fung, 2002). The Petrifilm system (3M Microbiology, St. Paul, MN) is one of these rapid methods and is widely used by food industries for monitoring microbiological contamination of food processing and final products (Blackburn et al., 1996). Several microorganism groups can be enumerated by distinct presentations of the system, and the Petrifilm Aerobic Count (AC) plates are commonly used for enumeration of MA.

Considering the need for reliable and adequate enumeration of MA in milk to provide proper quality control during production and processing, we compared the protocols of IDF/ISO, APHA, and MAPA for MA enumeration in raw and pasteurized milk samples, using the conventional plating methodology and Petrifilm AC plates.

Milk samples ( $\mathrm{n}=15$ of raw milk and $\mathrm{n}=15$ of pasteurized milk) were aseptically collected in a dairy industry in Viçosa (Minas Gerais, Brazil). All samples were kept under refrigeration until analysis, when they were submitted to 10 -fold serial dilution using $0.85 \%$ $\mathrm{NaCl}$ for microbiological procedures.

All diluted samples were submitted to MA enumeration by conventional plating and using Petrifilm AC plates, followed by incubation in different combinations of temperatures and periods of incubation, according to protocols described by IDF/ISO (ISO, 2003), APHA (Wehr and Frank, 2004), and MAPA (Brasil, 2003). Two dilutions from each sample were selected and pour plated with plate count agar (Becton Dickinson, Franklin Lakes, NJ) in duplicate. The same dilutions were plated in Petrifilm AC without replicates. The described plating procedures were conducted in triplicate for each sample, considering the distinct conditions of incubation described as follows.

Each triplicate plate (conventional and Petrifilm AC) was incubated under distinct conditions, according to IDF/ISO: $30^{\circ} \mathrm{C}$ for $72 \mathrm{~h}$ (ISO, 2003); APHA: $32^{\circ} \mathrm{C}$ for $48 \mathrm{~h}$ (Wehr and Frank, 2004); and MAPA: $36^{\circ} \mathrm{C}$ for 48 h (Brasil, 2003). After incubation, the colonies were enumerated and the final results expressed in colonyforming units per milliliter.

The obtained counts were converted to $\log _{10}$ and the mean values were compared by ANOVA to identify significant differences between the protocols and enumeration systems (conventional plating and Petrifilm; $P<0.05)$. In addition, the data were compared by correlation considering the same variables. All statistical analyses were processed using Statistica 7.0 software (StatSoft Inc., Tulsa, OK).

The mean values of MA obtained from raw and pasteurized milk samples by conventional plating and Petrifilm AC in each evaluated incubation condition are presented in Table 1 . Considering only the results obtained by the conventional procedure, the obtained data indicated equivalency between the incubation conditions for all types of samples, because no significant differences were observed $(P>0.05)$. Considering Petrifilm AC, no differences between the mean counts obtained under each incubation condition were observed for raw milk samples $(P>0.05)$. However, for pasteurized milk samples, the mean values obtained at $30^{\circ} \mathrm{C}$ for $72 \mathrm{~h}$ were significantly higher compared with the mean value at $32^{\circ} \mathrm{C}$ for $48 \mathrm{~h}$, which was also significantly higher than the mean value obtained at $36^{\circ} \mathrm{C}$ for $48 \mathrm{~h}(P<0.05)$.

Considering the comparison between the mean counts obtained in each system and incubation condition, sig- 
Table 2. Statistical correlation parameters between mesophilic aerobes counts of raw and pasteurized milk obtained by conventional plating or Petrifilm system incubated at 3 distinct conditions

\begin{tabular}{|c|c|c|c|c|c|c|c|}
\hline Comparisons (x:y) & \multicolumn{7}{|c|}{ Statistical correlation parameters ${ }^{1}$} \\
\hline $30^{\circ} \mathrm{C}, 72 \mathrm{~h}: 32^{\circ} \mathrm{C}, 48 \mathrm{~h}$ & 29 & 0.99 & 0.98 & 0.000 & 1.02 & -0.22 & 0.03 \\
\hline $30^{\circ} \mathrm{C}, 72 \mathrm{~h}: 36^{\circ} \mathrm{C}, 48 \mathrm{~h}$ & 28 & 0.99 & 0.98 & 0.000 & 0.99 & -0.24 & 0.07 \\
\hline $32^{\circ} \mathrm{C}, 48 \mathrm{~h}: 36^{\circ} \mathrm{C}, 48 \mathrm{~h}$ & 29 & 0.99 & 0.98 & 0.000 & 0.98 & -0.01 & 0.04 \\
\hline \multicolumn{8}{|l|}{ Petrifilm $\mathrm{AC}^{2}$ plating } \\
\hline $32^{\circ} \mathrm{C}, 48 \mathrm{~h}: 36^{\circ} \mathrm{C}, 48 \mathrm{~h}$ & 30 & 0.97 & 0.94 & 0.000 & 1.22 & -1.87 & 0.50 \\
\hline
\end{tabular}

${ }^{1} \mathrm{n}=$ number of repetitions; $\mathrm{r}=$ correlation index; $\mathrm{R}^{2}=$ determination coefficient; $P=$ level of significance; $\mathrm{a}=$ slope; $\mathrm{b}=$ intercept; mv $=$ mean variance.

${ }^{2}$ Petrifilm Aerobic Count plate (3M, St. Paul, MN).

nificant differences were only observed for pasteurized milk at $32^{\circ} \mathrm{C}$ for $48 \mathrm{~h}$ and $36^{\circ} \mathrm{C}$ for $48 \mathrm{~h}(P<0.05$; Table 1). The mean counts of MA obtained from raw milk samples at all incubation conditions, and pasteurized milk at $30^{\circ} \mathrm{C}$ for $72 \mathrm{~h}$ did not present significant differences $(P>0.05)$.

These results indicate that at higher incubation temperatures for $48 \mathrm{~h}$, a portion of pasteurized milk microbiota was not able to form visible colonies in Petrifilm AC plates, resulting in lower counts compared with the conventional plating procedure and incubation at $30^{\circ} \mathrm{C}$ for $72 \mathrm{~h}$ (Table 1). The probable cause for these differences is the presence of naturally occurring microbiota in pasteurized milk with low capability of reducing 2,3,5-triphenyltetrazolium chlorine (TTC; Beloti et al., 2002), the dye indicator used in Petrifilm $\mathrm{AC}$ plates to identify the formed colonies. Thermoduric microorganisms are typically present in pasteurized milk and they are known to be poor TTC reducers (Beloti et al., 1999).

The equivalency of incubation conditions by conventional plating procedure was confirmed by the data presented in Table 2. In all possible comparisons between the obtained results in each incubation condition, it was possible to verify excellent correlation indices. Considering the results obtained only by Petrifilm AC plates, interferences can be observed when the results from distinct incubation conditions are compared, mainly by inadequate values of slope (a) and intercept (b) (Table 2 ). When these data are compared considering only the plating system, the counts obtained from Petrifilm AC plates incubated at $30^{\circ} \mathrm{C}$ for $72 \mathrm{~h}$ presented excellent correlation indices with data obtained in distinct incubation conditions by conventional plating (Figure 1). However, as the incubation temperature increased, the slope (a) and intercept (b) varied and indicated some deficiencies on the performance of Petrifilm AC (Figure
1). These statistical parameters are useful to evaluate the correlation between the methodologies.

These data confirm the significance of pasteurized milk microbiota on the performance of Petrifilm AC. Beloti et al. (1999) reported that the majority of nonreducing TTC microorganisms are thermoduric, predominantly gram-positive bacteria (95.7\%), typically found in pasteurized milk. Nonetheless, several species of naturally occurring microorganisms in milk and dairy products are known for their low capability of reducing TTC (Swanson et al., 1992). These microorganisms are incapable of forming visible colonies in Petrifilm AC plates, and are not consequently enumerated. Streptococcus viridans is one of these microorganisms, and it is not able to produce characteristic red colonies in Petrifilm $\mathrm{AC}$ plates when incubated at $32^{\circ} \mathrm{C}$ for $48 \mathrm{~h}$, requiring $5 \mathrm{~d}$ for this (Dawkins et al., 2005). Other species from Streptococcus genera were described previously as poor or nonreducing TTC, such as Streptococcus cremoris (Turner et al., 1963) and Streptococcus thermophilus (Dawkins et al., 2005; Nero et al., 2006; Ortolani et al., 2007).

The obtained results suggest that $72 \mathrm{~h}$ of incubation is the required incubation period for Petrifilm $\mathrm{AC}$ plates for adequate development of colonies from microorganisms with low capability of reducing TTC from pasteurized milk. Considering this, the absence of difference between the mean counts obtained from Petrifilm AC plates and the conventional procedure (Table 1) and the better correlation indices (Figure 1) are adequately explained.

Despite the observed limitations related to Petrifilm $\mathrm{AC}$ performance for MA enumeration in pasteurized milk produced in Brazil (Beloti et al., 2002; present study), the convenience of this system for microbiological analysis in raw milk and other foods has been reported in previous studies (Park et al., 2001; Ellis and 

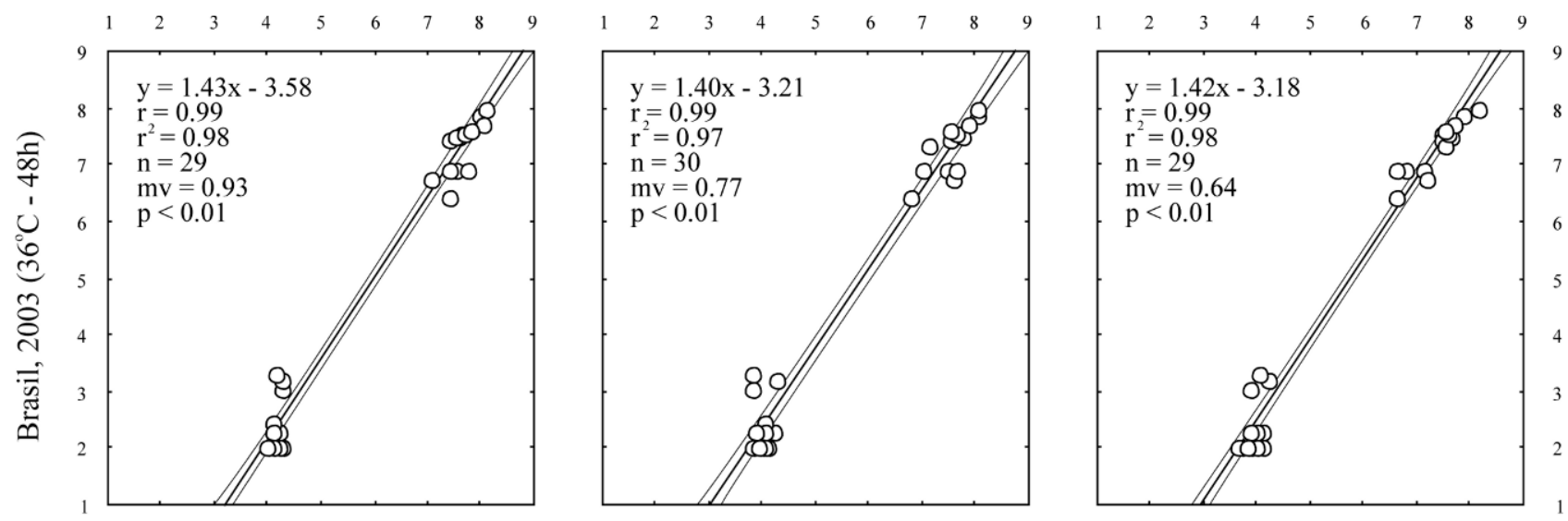

ב⿱
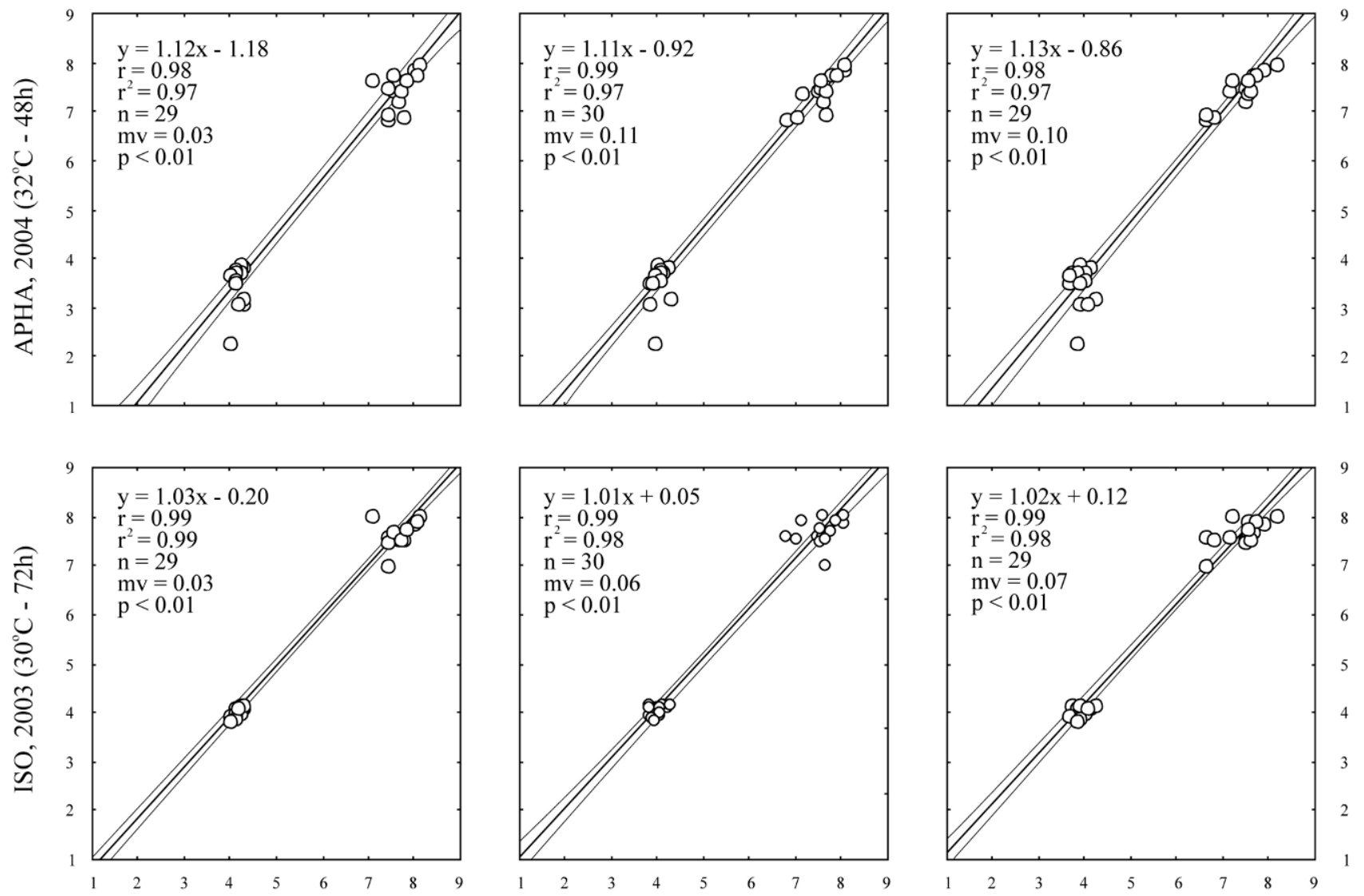

ISO, $2003\left(30^{\circ} \mathrm{C}-72 \mathrm{~h}\right)$

APHA, $2004\left(32^{\circ} \mathrm{C}-48 \mathrm{~h}\right)$

Brasil, 2003 (36 $\mathrm{C}-48 \mathrm{~h})$

\section{Conventional plating $\left(\log _{10} \mathrm{cfu} / \mathrm{mL}\right)$}

Figure 1. Dispersion of mesophilic aerobes counts in raw and pasteurized milk obtained by conventional (x-axis) and Petrifilm Aerobic Count (y-axis; Petrifilm, 3M, St. Paul, MN) plating and incubated at 3 distinct conditions $\left[30^{\circ} \mathrm{C}\right.$ for $72 \mathrm{~h}(\mathrm{ISO}, 2003) ; 32^{\circ} \mathrm{C}$ for $48 \mathrm{~h}(\mathrm{American}$ Public Health Association; Wehr and Frank, 2004); and $36^{\circ} \mathrm{C}$ for $48 \mathrm{~h}$ (Brasil, 2003)]. In each graphic: $\mathrm{y}=\mathrm{ax}+\mathrm{b}$ [correlation formula, indicating slope (a) and intercept (b); correlation index (r), determination coefficient $\left(\mathrm{r}^{2}\right)$; number of repetitions (n); mean variance (mv); and level of significance $(P)$. 
Meldrum, 2002; Tavolaro et al., 2005). The microbiota of the tested food is a determining factor for the performance of Petrifilm, but distinct incubation conditions can improve the efficiency of this system.

The obtained results indicate that the 3 tested incubation conditions can be similarly used for MA enumeration in raw and pasteurized milk by conventional plating procedures. As an alternative, Petrifilm AC plates can be used for MA enumeration in raw milk samples in any of the test incubation conditions. For pasteurized milk, significant interference of the autochthonous microbiota on the performance of Petrifilm AC was verified, which was partially corrected when the plates were incubated at $30^{\circ} \mathrm{C}$ for $7 \mathrm{~h}$. This condition apparently allowed for the adequate development of visible colonies from poor or nonreducing TTC microorganisms.

\section{ACKNOWLEDGMENTS}

Luís A. Nero was supported by Fundação de Amparo à Pesquisa do Estado de Minas Gerais (PPM-CVZ APQ-5946-5.04/07).

\section{REFERENCES}

Beloti, V., M. A. F. Barros, J. C. Freitas, L. A. Nero, J. A. Souza, E. H. W. Santana, and B. D. G. M. Franco. 1999. Frequency of 2, 3, 5-triphenyltetrazolium chloride (TTC) non-reducing bacteria in pasteurized milk. Rev. Microbiol. 30:137-140.

Beloti, V., M. A. F. Barros, L. A. Nero, J. A. S. Pachemshy, E. H. W. Santana, and B. D. G. M. Franco. 2002. Quality of pasteurized milk influences the performance of ready-to-use systems for enumeration of aerobic microorganisms. Int. Dairy J. 12:413-418.

Blackburn, C. W., C. L. Baylis, and S. B. Petitt. 1996. Evaluation of Petrifilm $^{\mathrm{TM}}$ methods for enumeration of aerobic flora and coliforms in a wide range of foods. Lett. Appl. Microbiol. 22:137-140.

Brasil. 2002. Ministério da Agricultura, Pecuária e Abastecimento: Regulamentos técnicos de produção, identidade e qualidade do leite tipo A, do leite tipo B, do leite tipo $\mathrm{C}$, do leite pasteurizado e do leite cru refrigerado e o regulamento técnico da coleta de leite cru refrigerado e seu transporte a granel. Normative instruction n. 51, from Sep. 18, 2002. Diário Oficial da União, Sep. 21, 1:13.

Brasil. 2003. Ministério da Agricultura, Pecuária e Abastecimento: Métodos analíticos oficiais para análises microbiológicas para controle de produtos de origem animal e água. Normative instruction n. 62, from Aug. 26, 2003. Diário Oficial da União, Sep. 18, 1:14.

Brasil. 2008a. Ministério da Agricultura, Pecuária e Abastecimento. http://www.agricultura.gov.br Accessed Sep. 12, 2008.
Brasil. 2008b. Agência Nacional de Vigilância Sanitária-Ministério da Saúde. http://www.anvisa.gov.br Accessed Sep. 12, 2008.

Dawkins, G. S., J. B. Hollingsworth, and M. A. E. Hamilton. 2005. Incidences of problematic organisms on Petrifilm ${ }^{\mathrm{TM}}$ Aerobic Count plates used to enumerate selected meat and dairy products. J. Food Prot. 68:1506-1511.

Ellis, P., and R. Meldrum. 2002. Comparison of the compact dry TC and $3 \mathrm{M}$ Petrifilm ${ }^{\mathrm{TM}}$ ACP dry sheet media methods with the spiral plate method for the examination of randomly selected foods for obtaining aerobic colony counts. J. Food Prot. 65:423-425.

Fung, D. Y. C. 2002. Rapid methods and automation in microbiology. Comp. Rev. Food Sci. 1:3-22.

ICMSF. 1988. Microorganisms in Foods 1: Their Significance and Methods of Enumeration. 2nd ed. International Commission of Microbiological Specifications in Foods, Toronto, Canada.

ISO. 2003. ISO 4833:2003 Microbiology of food and animal feeding stuffs - Horizontal method for the enumeration of microorganisms: Colony-count technique at $30^{\circ} \mathrm{C}$. International Organization for Standardization, Geneva, Switzerland.

Jay, J. M., M. J. Loessner, and D. A. Golden. 2005. Modern Food Microbiology. Chapman and Hall, New York, NY.

Nero, L. A., V. Beloti, M. A. F. Barros, M. B. T. Ortolani, R. Tamanini, and B. D. G. M. Franco. 2006. Comparison of Petrifilm ${ }^{\mathrm{TM}}$ Aerobic Count Plates and de Man-Rogosa-Sharpe Agar for enumeration of lactic acid bacteria. J. Rapid Methods Autom. Microbiol. 14:249257.

Ortolani, M. B. T., G. N. Viçosa, V. Beloti, and L. A. Nero. 2007. Screening and enumeration of lactic acid bacteria in milk using three different culture media in Petrifilm ${ }^{\mathrm{TM}}$ Aerobic Count plates and conventional pour plate methodology. J. Dairy Res. 74:387391.

Park, Y. H., K. S. Seo, J. S. Ahn, H. S. Yoo, and S. P. Kim. 2001. Evaluation of the Petrifilm ${ }^{\mathrm{TM}}$ Plate method for the enumeration of aerobic microorganisms and coliforms in retailed meat samples. J. Food Prot. 64:1841-1843.

Robinson, R. K. 2002. Dairy Microbiology Handbook. 3th ed. WileyInterscience, New York, NY.

Sant'Ana, A. S., C. Conceição, and D. R. P. Azeredo. 2002. Comparação entre os métodos rápidos Simplate TPC-CI e Petrifilm ${ }^{\mathrm{TM}}$ AC e os métodos convencionais de contagem em placas para a enumeração de aeróbios mesófilos em sorvetes. Ciên. Tecnol. Alim. 22:60-64.

Swanson, K. M. J., F. F. Busta, E. H. Peterson, and M. G. Johnson. 1992. Colony count methods. Pages 75-95 in Compendium of Methods for the Microbiological Examination of Food. F. P. Pouch and K. Ito, ed. American Public Health Association, Washington, DC.

Tavolaro, P., A. R. Ferrati, M. T. Destro, M. Landgraf, and B. D. G. M. Franco. 2005. Performance of two ready-to-use systems for enumeration of aerobic mesophilic microorganisms in frozen goat milk. Braz. J. Microbiol. 36:295-300.

Turner, N., W. E. Sandine, P. R. Elliker, and E. A. Day. 1963. Use of tetrazolium dyes in an agar medium for differentiation of Streptococcus lactis and Streptococcus cremoris. J. Dairy Sci. $46: 380-385$

Wehr, H. M., and J. F. Frank. 2004. Standard Methods for the Examination of Dairy Products. American Public Health Association, Washington, DC. 